\title{
Delineation of human thymocytes with or without functional potential by CD1-specific antibodies
}

\author{
Antonio de la Hera, Maria-Luisa Toribio', and Carlos Martinez-A. ${ }^{1}$ \\ Basel Institute for Immunology, $\mathrm{CH} .4005$ Basel, Switzerland \\ 'Centro de Bıologia Molecular, CSIC, Unıversidad Autonoma, Campus de Cantoblanco, 28049 Madrid, \\ Spain
}

Key words: T cell precursors, CD1-multımolecular complexes, Immature thymocytes

\begin{abstract}
Hematopoletic precursors lacklng T cell antigen receptors (TCR-CD3-) and CD4 and CD8 surface markers (I.e. double-negative thymocytes) give rlse to functionally mature T lymphocytes. Yet their major progeny are immunologically unresponsive thymocytes in spite of having acquired TCR - CD3 and CD4 - CD8. Because only mature thymocytes migrate to peripheral lymphold organs and most thymocytes die in situ, the knowledge of the events associated with functional maturation in the double-negative thymocyte progeny is a fundamental question in $T$ cell development. We reasoned that a clue to trace the fate of early human thymocytes may perhaps come from the study of the developmental acquisition of CD1 antigen, currentiy used to define better the functionally Inert CD4+8+ (double-positlve) stage and absent In mature, medullary thymocytes and peripheral T cells. By using antibodles specific for CD1 (HTA 1/T6) we show here that a large fractlon of double-negative thymocytes also express CD1. CD1+3-, CD1+3+, CD1-3+, and CD1-3- subsets all exlst. The CD1+3- subset generates CD1+3-4-8+ precursors of CD1 + double-positive cells. A large portion of the $\mathrm{CD} 1+3+8$ bset bears TCR $\delta-\mathrm{CD} 3$ complexes. The CD1 - subsets are responsive In assays of function, in which they can be stimulated to use the interleukin 2 pathway of proliferation and to medlate cytotoxicity. In contrast, all CDi+ thymocytes behave as functlonally inert cells. Thus, the CD1 surface marker delineates humen thymocyte precursors and their products which lack, or possess, functlonal potential in vitro, on both $\alpha \beta$ and $\gamma \delta$ lineages.
\end{abstract}

\section{Introduction}

Triggering of resting peripheral T cells occurs through occupancy of the antigen receptors, $\alpha \beta$ or $\gamma \delta$ heterodimers assoclated with CD3 (TCR - CD3 complex) and CD4 or CD8 co-receptors. TCR ligands stimulate $T$ cell proliferation via the antıgen-non-specific, interleukın 2 receptor (IL2-R)/IL2 growth pathway. Such activated, mature $T$ cells can mediate helper or cytotoxic effector functions in an antigen-specific fashion upon a later occupancy of the TCR (1)

Acquisition of TCR - CD3, CD4, and CD8, as well as T cell associated function programs, occurs during $T$ cell development in the thymus $(2,3)$. Three sub-populations of thymocytes have been defined on the basis of their antigen receptor phenotype and their functional competence: early precursors and either immunologically unresponsive (inert) or mature thymocytes $(4,5)$. The early thymocytes, which lack surface expression of TCR - CD3, CD4, and CD8 receptors, give rise to some phenotypically and functionally mature thymocytes which can migrate to the periphery (6). Yet their major progeny are functionally unresponsive thymocytes, despite the fact that about half of them co-express TCR - CD3, CD4, and CD8 on the membrane (5-9). The events signaling the functional fate of early thymocyte progeny are thus a fundamental question in T cell development because inert thymocytes do not migrate to the perıphery (7).

The most striking finding of the functional studies performed with thymocytes is their lack of correlation with antigen receptor expression $(9-11)$. We reasoned that a clue to trace the functional fate of early thymocytes may perhaps come from developmental analyses of a third type of cellsurface marker that, unlike TCR - CD3 complex or CD4 and CD8, were selectively expressed on inert thymocytes. It has been previously shown that CD1 (HTA 1/T6) occurs on functionally inert human $\mathrm{CD} 4+8+$ double-positive thymocytes but not in immunocompetent thymocytes or peripheral T cells $(4,12-14)$. We have therefore studied the expression of CD1 on human early

Correspondence to. Antonio de la Hera, Basel Institute for Immunology, Grenzancherstrasse 487, Postlach CH-4005 Basel, Switzerland 
thymocytes using CD1-specific antıbodies. We show here that subsets of $\mathrm{CD}^{-}$- and $\mathrm{CD} 3$ + double-negative thymocytes also express CD1 antigen on their surfaces. CD1- subsets contain mature $\alpha \beta$ and $\gamma \delta$ T cells, whereas CD1 + subsets behave like inert thymocytes belonging to $\alpha \beta$ and $\gamma \delta$ lineages.

\section{Methods}

\section{Isolation of cells}

Single cell suspensions were obtained from normal pediatric thymus that had been removed during corrective cardiac surgery of patients 2 weeks -5 years old. Viable thymocytes were isolated by Ficoll - Hypaque densty centrifugation (15) Double-negative thymocytes were isolated by immunoselection using cytotoxic antibodies to CD4 (HP2/6) and CD8 (B9.4) plus a 1:4 dilution of selected rabbit complement (Beringwerke, Marburg. FRG) $(3,15)$. The surviving cells $\left(99 \% \mathrm{CD}^{-} \mathbf{-}^{-}\right)$were incubated with either anti-CD1 (OKT6, $\gamma$, antibody) (CD1+3-4-8- cells), antiCD3 (T3b, $\gamma_{2 a}$ ) antibody $(\mathrm{CD} 1-3+4-8-$ cells), or both (CD1 $+3+4-8-$ and CD1-3-4-8- cells), and the respective populatıon positively or negatively selected after incubation with affinity-purified rabbit anti-mouse $ı$ munoglobulın for $1 \mathrm{~h}$ at $4^{\circ} \mathrm{C}$. The CD1+3 + subset behaves as total CD1 + cells For accuracy in some experıments, Including ones in thıs report, the mınor $\mathrm{CD} 1+3+$ subset within the $\mathrm{CD} 1+$ or $\mathrm{CD} 3+$ selected population was depleted by incubation with either cytotoxIc CD3 (T3b) or CD1 (Na1/34) antibodies plus complement. CD1-3-4-8- thymocytes express CD7 and CD2 T cell differentiation antigens in vivo (15 and data not shown). CD3-4-8+ thymocytes were isolated after two rounds of cytotoxic elimination with monoctonal antibody (mAb) CD3 (T3b) and CD4 (OKT4A) plus complement followed by positive selection with mAb CD8 (B9 $4, \gamma_{20}$ ) in flasks coated with goat anti-mouse $\gamma_{2 b}$ antibodies (Southern Biotechnology, Birmıngham, AL, USA). Most recovered cells expressed CD1. All purified populations were $>98 \%$ pure by FACS analyses An intracardiac blood sample was obtaned before establishment of the extracorporeal bypass circulation. Mononuclear cells were separated by Ficoll - Hypaque density centrifugation.

\section{mAbs}

CD1 [OKT6, $\gamma_{1}$, Amerıcan Type Culture Collectıon, Rockville, MD, USA, Na1/34 (12), $\gamma_{2 a}$, or Coulter Clone T6, Coulter], CD2 [MAR $206.1(16), \gamma_{1}$ ], CD3 [T3b (17), $\gamma_{2 a}$ and Coulter Clone T3], CD4 [HP2/6 $\gamma_{2}$ (16), Leu3a, Becton-Dickinson, $\gamma_{1}$, or OKT4A, Ortho, Raritan, NJ, USA, $\gamma_{2 a}$ ], CD7 [3A1, American Type Culture Collection, Rockville, MD], CD8 [B9.4 (18), $\gamma_{2 b}$ ], TCR $\alpha \beta$ [WT31 (19), $\gamma_{1}$ ], TCR $\gamma \delta$ [TCR $\delta 1$ (20), $\gamma_{1}$ ], TCR-V $\delta 1$ [TCS $\delta 1, T$-cell Sciences, Boston, MA, USA], TCR-V $V_{\gamma 9}[T-\gamma A(21)$, $\gamma_{2 \mathrm{a}}$ ], and CD25 [Tac chain of the IL2R, H108 (16)] were used

\section{Quantitative flow cytometry}

Two-color immunofluorescence studies were carried out as previously described (22). Cells were staned in sequential steps.
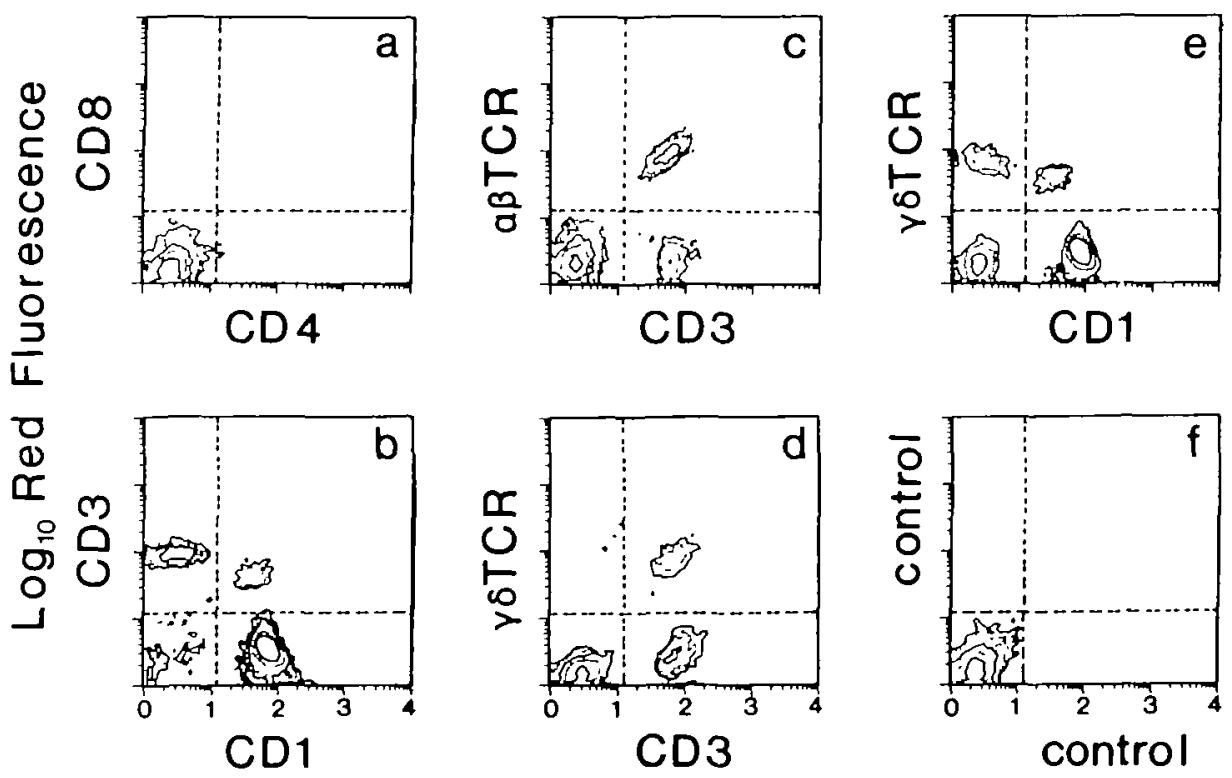

\section{$\log _{10}$ Green Fluorescence}

Fig. 1. Two-color immunofluorescence $\mathrm{FC}$ analyses for co-ordinate expression of CD1, CD3, $\alpha \beta$, and $\gamma \delta$ TCRs in CD4-8- thymocytes. Doublenegative thymocytes were Isolated using cytotoxic antibodies to CD4 (HP2/6) and CD8 (B9.4) plus rabbit complement (Berıngwerke, Marburg, FRG), and two-color FC studies were carried out as described in Methods Briefly, thymocytes were stanned by indirect immunofluorescence Reagents included mAbs of predefined isotype CD1 [(b) OKT6, $\gamma 1$, or (e) Na1/34, $\gamma_{2 a}$ ], CD3 [T3b, $\gamma_{2 a}$ ], CD4 [Leu3a, $\gamma_{1}$ ], CD8 [B9 4, $\gamma_{2 b}$ ], $\alpha \beta$ TCR [WT31, $\gamma_{1}$ ], and $\gamma \delta$ TCR [TCR $\delta 1, \gamma_{1}$ ], followed by ether FITC (green)-conjugated or PE (red)-labeled goat anti-mouse isotype-specific second step reagents. Prelımınary studies showed that each anti-isotype antibody did react with one but not the other primary antibody Experıments using directly labeled antibodies yield similar results (Table 1). FC analyses were performed in a FACScan analyzer equipped with a four decade log amplifier and $10^{4}$ viable cells were accumulated in each contour plot Background values are indicated by dotted lines. Percentages of positive cells in each quadrant are indicated in the text for clanty Results are representative of six independent experiments. 
Reagents included mAbs of predefined isotype, as indicated, followed by either fluoresceln Isothiocyanate (FITC; green)conjugated or phycoerythrın (PE; red)-labeled goat anti-mouse isotype-specific second step reagents (Southern Bıotechnology). Background values are indicated by dotted lines and were obtained using isotype-matched, irrelevant antibodies and their respective second antibodies. These procedures rule out any artifice due to carry over of mAb from the cytotoxic incubation (23). Percentages of positive cells in each quadrant are indicated in the text for clarity. Two-colour flow fluorocytometry (FC) analyses were performed in a FACScan analyzer interfaced to a Consort 30 (Beckton-Dickinson).

\section{Assays for differentiation}

CD1+3-4-8- or CD3-4-8+ cells were ssolated from thymocyle populations as indicated above. They were stained, either fresh or after their culture in the presence of $50 \mathrm{U} / \mathrm{ml} \mathrm{rlL2}$ (3) for $36 \mathrm{~h}$, with mAbs specific for the Indicated combinations of $T$ cell differentiation antıgens and analyzed for two color immunofluorescence and FC.

\section{Assays for function}

(1) To quantitate IL2 secretion, $2 \times 10^{6}$ cells in each doublenegative subset were stimulated with $5 \mu \mathrm{g} / \mathrm{ml}$ phytohemagglutının
(PHA) and $25 \cup$ rlL1 $\beta$ (Hoffmann-LaRoche, Inc , Nutley, NJ, USA) for $36 \mathrm{~h}$. Supernatants were collected and IL2 activity measured using the IL2-dependent CTLL2 lıne in trıplicate cultures, and the sensitıve hexoseamınıdase read-out assay (15). Units were calculated as indicated (15) and compared to a rlL2 control (Hoffmann-LaRoche, no. R023-6019). (II) The expression of the p55 chan of the IL2R (Tac or CD25) was measured either on freshly isolated thymocytes or after their stimulation $\left(2 \times 10^{6}\right.$ cells) with $5 \mu \mathrm{g}$ PHA for $24 \mathrm{~h}$, using biotin-conjugated anti-Tac $(\mathrm{H} 108)$ antibody followed by PE-labeled streptavidin (BectonDıckınson). (iii) Proliferative cell responses of $2 \times 10^{5}$ cells cultured with either $50 \mathrm{U}$ rlL2 or $5 \mu \mathrm{g} / \mathrm{ml}$ PHA and $25 \mathrm{U}$ rlL1 $\beta$ were carried out at $37^{\circ} \mathrm{C}$ for $80 \mathrm{~h}$ in triplicate cultures in 96-well microtiter plates. $\left[{ }^{3} \mathrm{H}\right]$ Methylthymidine uptake $(1 \mu \mathrm{Ci} /$ well) was measured during the last $11 \mathrm{~h}$ of culture (15) (iv) For quantitation of cytotoxic activity, effector cells were cultured for 4 days at $10^{8}$ cells $/ \mathrm{ml}$ in $50 \mathrm{U} / \mathrm{ml}$ rlL2. Their cytotoxic activity was assessed against ${ }^{51} \mathrm{Cr}$-labeled $\mathrm{P}-815$ cells ether uncoated or coated (24) with T3b (CD3)-, WT31 (TCR $\alpha \beta)$-, or TCR $\delta 1$ (TCR $\gamma \delta)$-specific antibodies. MAR206.1 antibody (CD2) gave similar results to those obtained with uncoated target cells (not shown) The $4 \mathrm{~h}$ ${ }^{51} \mathrm{Cr}$-release assay was performed as described elsewhere (24). The results are expressed as the mean ${ }^{51} \mathrm{Cr}$ specific release of triplicate cultures at $25 / 1$ effector-to-target ratı. Spontaneous release never exceeded $18 \%$.

Table 1. Detection of CD1+ TCR $\delta-C D 3+$ cells in the thymus but not in peripheral blood

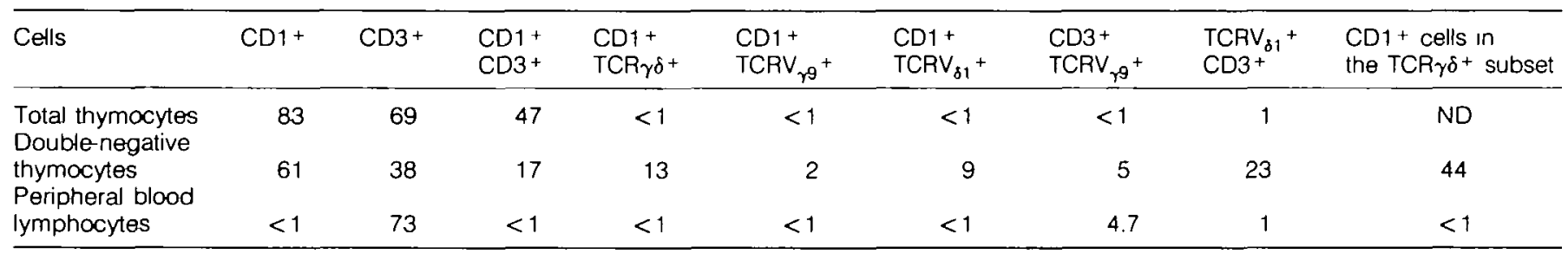

The indicated cell populations were isolated and two-color FC studies were carried out as described in Fig 1 Here direct immunofluorescence was used. Antibodies in the upper row were conjugated with PE (red) and those in the lower row were FITC (green). The proportion of CD1+ cells In the $\gamma \delta$ population was calculated by two-color FC measuring the number of CD1+ cells (red) after electronically gating in the TCR $\gamma \delta+$ subset (green). Reagents were Coulter Clone T6 (CD1), Coulter Clone T3 (CD3), TCR $\delta 1$ (TCR $\gamma \delta$ ), Ti- $\gamma$ A (TCR-V $v_{\gamma g}$ ), and TCS $\delta 1$ (TCR-V $\delta_{\delta 1}$ ) Results show the percentages of positive cells in a child representative of four simılar cases studied, ND, not done

Table 2. Immunological unresponsiveness of the CD1+ subset of CD4-8- double-negative thymocytes

\begin{tabular}{|c|c|c|c|c|c|c|c|c|c|}
\hline \multirow[t]{2}{*}{ Cell populatıons ${ }^{a}$} & \multirow{2}{*}{$\begin{array}{l}\text { (a) IL2 secretion } \\
(\mathrm{U} / \mathrm{ml}) \\
\text { PHA + IL } 1 \beta\end{array}$} & \multicolumn{2}{|c|}{$\begin{array}{l}\text { (b) Tac expression } \\
\text { (\%) positive cells) }\end{array}$} & \multicolumn{2}{|c|}{$\begin{array}{l}\text { (c) Proliferatıon } \\
\left(\mathrm{cpm} / \mathrm{min} \times 10^{-3}\right)\end{array}$} & \multicolumn{4}{|c|}{$\begin{array}{l}\text { (d) Antıbody retargeted cytotoxicity } \\
\left(\% \text { specific }{ }^{51} \mathrm{Cr} \text { release) }\right.\end{array}$} \\
\hline & & fresh & PHA activated & rlL2 & $\mathrm{PHA}+\mathrm{rlL} 1 \beta$ & None & $\mathrm{CD} 3$ & $\operatorname{TCR} \alpha \bar{\beta}$ & $\overline{\mathrm{TCR}} \gamma \delta$ \\
\hline CD $1-3-4-8-$ & 63 & 46 & 76 & 87 & 189 & 5 & $55^{a}$ & 38 & 33 \\
\hline $\mathrm{CD} 1+3-4-8-$ & 01 & 1 & 1 & 0.9 & 3 & 1 & 2 & 1 & 0 \\
\hline $\mathrm{CD} 1-3+4-8-$ & 33 & 8 & 52 & 15 & 161 & 2 & 68 & 49 & 23 \\
\hline $\mathrm{CD} 1+3+4-8-$ & 0.2 & 2 & 6 & 18 & 7 & 3 & 3 & 2 & 1 \\
\hline
\end{tabular}

Function assays were (see Methods for details), (a) IL2 secretion promoted by PHA plus riL $1 \beta$ was estımated using IL2-dependent mouse CTLL2 cells, which respond to human riL2 but not rlL4, (b) Tac expression in fresh or PHA activated cells was evaluated using H108 antbody and flow cytometry, (c) proliferation was measured by $\left[{ }^{3} \mathrm{H}\right]$ thymidine incorporation after $80 \mathrm{~h}$ of culture with rlL2 or PHA + rlL $1 \beta$; and (d) Cytolytic potential was assessed against ${ }^{51} \mathrm{Cr}$-labeled P-815 cells erther uncoated or coated (24) with T3b (CD3)-, WT31 (TCR $\left.\alpha \beta\right)$ ), or TCR $\delta 1$ (TCR $\delta \delta$ )-specific antibodies CD2 antibody (MAR206 1, $\gamma_{1}$ ) gave similar results to those obtained with uncoated target cells (not shown) The results are expressed as the mean ${ }^{51} \mathrm{Cr}$ specific release of triplicate cultures at a 25/1 effector-to-target ratio Spontaneous release never exceeded $18 \%$.

a See Methods. The data presented here were obtaned in a simultaneous experiment: similar results were obtanned in five experiments

bCD1-3-4-8- thymocytes express CD7 and CD2 T cell differentiation antigens in wvo (15, and data not shown), and acquire TCR - CD3 complex and cytotoxic actıvity upon culture with rIL2 $(3,22)$ 


\section{Results}

Isolation of early $T$ cell precursors from postnatal thymus requires their separation from inert and mature thymocytes $(3,4)$. In the human system we have used anti-CD1 antıbodies to ald in the depletion of ınert cells. Combıned with anti-CD4 and anti-CD8 antıbodies, we obtanned a high proportion of TCR-CD3+ mature thymocytes in the double-negative isolate $(2,15)$. In the mouse system others have used anti-CD5 antibody to aid in the depletion of mature cells when preparing CD4-8- thymocytes (6). Unexpectedly, anti-CD5 antibody treatment depletes the above TCR-CD3 + mature subset of double-negative thymocytes (26). We thought that perhaps the depletion of CD1 + cells in our previous studies could have elımınated an Inert CD1+4-8- precursor subset (23)

We have now tested this possibility by using two-color fluorescence staınıng and $F C$ and assessing the co-ordinate expression of CD1, TCR $\alpha \beta-\mathrm{CD} 3$, and TCR $\gamma \delta-\mathrm{CD} 3$ on total CD4-8- thymocytes. Figure ta shows that only CD4-8thymocytes are left after treatment of thymocytes with anti-CD4 and -CD8 cytotoxic antibodies and complement. Figure $1 \mathrm{~b}$ shows the distribution of CD1 and CD3 surface molecules on doublenegative thymocytes. We found that $44 \%$ of double-negative thymocytes were $\mathrm{CD1}+3^{-}, 13 \%$ were $\mathrm{CD} 1+3^{+}, 14 \%$ were CD1-3-, and $29 \%$ were $\mathrm{CD} 1-3^{+}$. We also studied the presence of $\mathrm{TCR} \boldsymbol{\alpha} \beta-\mathrm{CD} 3+$ and $\mathrm{TCR} \gamma \delta-\mathrm{CD} 3+$ thymocytes among the double-negative thymocyte subset by using the panTCR $\alpha \beta$ monoclonal antibody WT31 and ant।-TCR $\delta 1$ antıbody specific for a framework determınant of the human TCR $\delta$ chain We found among the population of double-negative thymocytes $29 \%$ TCR $\delta 1+\mathrm{CD}^{+}{ }^{+}, \quad 13 \%$ WT3 $1+\mathrm{CD} 3+$, and $58 \%$ TCR $\delta 1$ WT31-CD3- cells (Fig. $1 \mathrm{c}$ and d). We also found a mınor population $\mathrm{CD} 3+\mathrm{TCR} \delta 1+$ (Fıg. 1d) among the CD1+ double-negatives $(8-13 \%$, Fig 1e). Simılarly a CD1+3+WT31+ minor subset also exists (1-6\%, data not shown) As shown in Table 1 , a subset of $\gamma \delta$ T cells in thymus but not in autologous peripheral blood co-expresses TCR $\gamma \delta$ and CD1. Moreover, studies using antıbodies specific for TCRs using $V_{\gamma 9}$ and $V_{\delta 1}$ regions $(21,27)$ showed a preferential use of $V_{\delta 1}$ in the thymus and $V_{\gamma \theta}$ in the periphery

Mature single-positive thymocytes respond to polyclonal $T$ cell activators (i e. PHA, anti-CD3 antibody) with IL2R expression, IL2 secretion, proliferation, and subsequent expression of effector functions (1.e. cytotoxicity) $(1,5)$. We isolated the $\mathrm{CD} 1+3^{+}$, CD1+3-, CD1-3+, and CD1-3- double-negative subpopulations by panning and carried out a comparative study of these functions with the purified double-negative thymocyte subsets. Table $2 a$ shows that the $\mathrm{CD} 1+3-$ and $\mathrm{CD} 1+3+$ populations, the CD1-positive subsets, did not secrete IL2 upon stimulation with PHA plus rlL1 $\beta$, while the CD1-negative subsets, either $\mathrm{CD} 3-$ or $\mathrm{CD} 3+$, did so. Approximately $46 \%$ unstımulated CD1-3- double-negative thymocytes expressed IL2R $\alpha$ (Tac,p55); unstimulated CD1-3+ double-negative thymocytes had barely detectable levels of IL2R $\alpha$ but both the number of positive cells and the levels of IL2R $\alpha$ increased after their stımulation with PHA. In contrast, CD1+ double-negative thymocytes did not express IL2R $\alpha$ under any of the conditions studied (Table $2 b$ ). The ability to express IL2R $\alpha$ correlated well with the proliferative responses driven by IL 2 alone or by PHA plus rIL1 $\beta$ (Table $2 \mathrm{c}$ ). The CD1-3-double-negative populatıon exhibited the best responses to IIL2, the CD1-3+ population responded to a lesser extent and the $C D 1+$ subsets were unresponsive. The CD1-3+, which can express IL2R $\alpha$ after

Table 3. Mitogenıc combination of either antı-CD2 or anti-CD3 antibodies stimulate proliferation in IL2 in CD1-3+ but not $\mathrm{CD} 1+3+$ double-negative thymocytes

\begin{tabular}{|c|c|c|c|c|c|c|c|c|}
\hline \multirow[t]{3}{*}{ Thymocyte subset ${ }^{a}$} & \multicolumn{8}{|c|}{$\left[{ }^{3} \mathrm{H}\right]$ Thymidine incorporation $\left(\mathrm{cpm} \times 10^{-3}\right)$} \\
\hline & \multicolumn{3}{|c|}{$\mathrm{CD} 2+\mathrm{rlL} 2$} & \multicolumn{3}{|c|}{$\mathrm{CD} 3+\mathrm{rlL} 2$} & \multicolumn{2}{|c|}{ None } \\
\hline & $\overline{\mathrm{d} 2}$ & d3 & d4 & $\mathrm{d} 2$ & d3 & $\mathrm{d} 4$ & $\mathrm{~d} 2$ & d3 \\
\hline $\mathrm{CD} 1+3+4-8-$ & 22 & 3.7 & 510 & 18 & 32 & 4.8 & 2.3 & 0.7 \\
\hline $\mathrm{CD} 1-3+4-8-$ & 17 & 33 & 81 & 24 & 47 & 107 & 12 & 04 \\
\hline Total & 5 & 13 & 29 & 8 & 19 & 40 & 08 & 02 \\
\hline
\end{tabular}

Thymocytes, $2 \times 10^{5}$ per microtiter tray well, were Incubated for 2, 3, or 4 days under the indicated culture conditions, rIL2 was added at $50 \mathrm{U} / \mathrm{ml}$, the mitogenıc pair of CD2 antibodies was D66 1 (38) + MAR 2061 , and antl-CD3 antibody was in solıd phase (plate-bound, $1 \mu \mathrm{g} / \mathrm{ml}$ T3b) (39) Results represent the average counts of triplicate determinations

aThymocyte subsets were either unfractionated or fractionated as indicated in Table 2

blt is noteworthy that a few prolferating cells occur in cultures of the poorly responsive $\mathrm{CD} 1+3^{+}$double-negative subset. Phenotypic analyses of these cells showed that they were CD1 - T cells (data not shown)
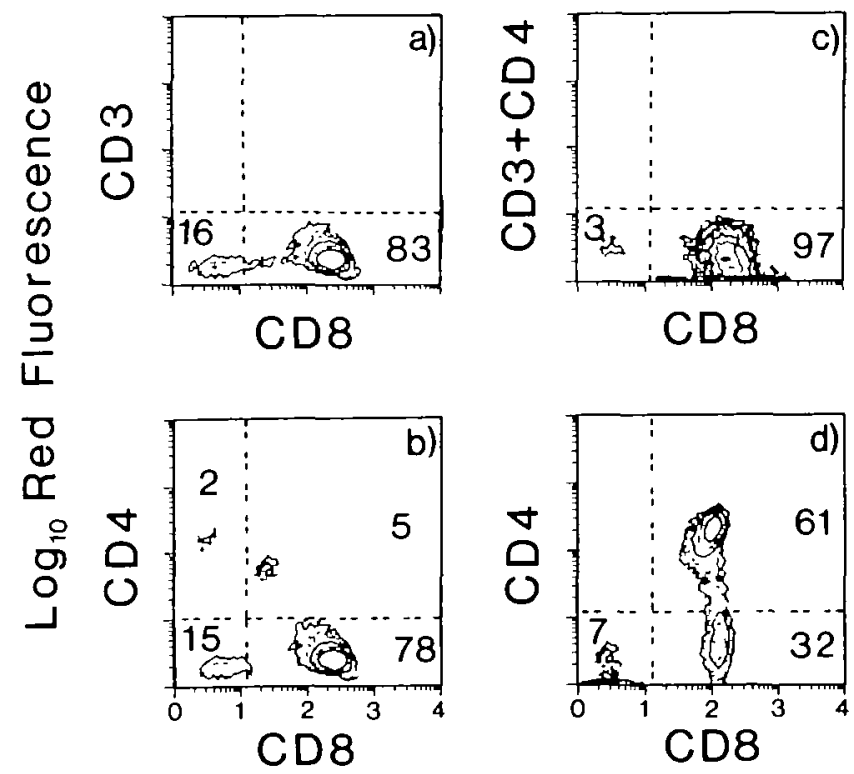

\section{$\log _{10}$ Green Fluorescence}

Fig. 2. Development in vitro of human double-positive thymocytes $\mathrm{CD} 1+3-4-8-(\mathrm{a}$ and $\mathrm{b}$ ) or CD3-4-8+ (c and d) cells were isolated and stained, either fresh (c) or atter their culture in the presence of $50 \mathrm{U} / \mathrm{ml}$ rll 2 for $36 \mathrm{~h}\left(\mathrm{a}, \mathrm{b}\right.$, and d), with $\mathrm{CD8}\left(B 9.4, \gamma_{2 b}\right),(a) \operatorname{CD} 3\left(\mathrm{~T} 3 \mathrm{~b}, \gamma_{2 \mathrm{a}}\right)$, or (b) CD4 (OKT4A, $\gamma_{2 a}$ ) in the indicated combinations, followed by the respectrve isotype-specific, fluorochrome-conjugated second antibody. Numbers in each contour-plot panet $(a-d)$ represent the percentage of positive cells in every quadrant Note the CD3 + CD4 legend in panel (c) indicates that cells were smultaneously incubated with CD3 and CD4 $\gamma_{2 a}$ mAb iollowed by PE conjugated $\gamma_{2 a}$-specific second antibody Similar results were obtained wth four independent thymuses 
activation (Table $2 b$ ), exhibited proliferatıve responses to PHA plus rIL $1 \beta$, while the CD1 + thymocytes neither expressed IL2R nor proliferated. The lack of proliferative responses in $\mathrm{CD1}{ }^{+}$ subsets is not due to the absence of CD1- cells or factors released by them in culture. In complementation experiments the CD1 + subset failed to proliferate in the presence of irradiated CD1 - double-negative thymocytes (data not shown). CD1-3and $\mathrm{CD} 1-3+$ double-negative thymocytes generated $\mathrm{CD} 3+$ cytotoxic cells $(3,22)$ that killed ant-TCR/CD3-coated targets while the CD1 + populations did not (Table 2d). It is still possible that differences in the ability of CD1 + and CD1 - subsets to use IL1 or bind PHA account for the CD1+ cells' unresponsiveness. We therefore analyzed the proliferative responses of $\mathrm{CD} 1+3+$ and CD1-3+ double-negative cells to antibodies binding to wellestablished membrane ligands. We found that CD1-3+ but not $\mathrm{CD} 1+3^{+}$double-negative cells proliferated in response to mitogenic combinations of anti-CD2 or anti-CD3 antibodies in the presence of IL2 (Table 3).

The findings of non-functional CD1 + double-negative thymocytes and that $\sim 95 \%$ of double-positive thymocytes express CD1 on the cell membrane raised the possibility that CD1+ doublenegative thymocytes would contain precursors for CD1+ double-postive thymocytes. That this is indeed the case is shown in the results depicted in Fig. 2. We found that CD1+3-4-8+ thymocytes give rise to CD1+3-4-8- thymocytes in culture (Fig. $2 \mathrm{a}$ and b). Differentiation was achieved in medium only, was not modified by the addition of exogenous IL2, and was readily evident after $24 \mathrm{~h}$ of culture. Some CD4 + and double-positive cells started to accumulate in the culture after $36 \mathrm{~h}$ (Fig. 2b), and the frequencies of double-positive cells quickly increased thereafter (data not shown). Because the recovenes of viable cells began to drop by $\sim 50 \%$ every $24 \mathrm{~h}$, after 2 days in culture it was difficult to discrimınate whether CD1+3-4-8+ cells acted as intermediate precursors of such CD4+8+ cells. To study this possibility, a population of CD1 $+3-4-8+$ thymocytes found in normal human thymus was isolated ex vvo ( $F(g .2 c)$. We found that after short-term culture these cells gave rise to $\mathrm{CD} 1+4+8+$ double-positive thymocytes (Fig 2d).

\section{Discussion}

We have studied the correlated distribution of CD1 antigen and $\alpha \beta$ and $\gamma \delta$ TCR - CD3 complexes on the surface of doublenegative thymocytes and found that CD1 is acquired at early stages of development, i.e. on some TCR-CD3- and $\mathrm{TCR}-\mathrm{CD} 3+$ double-negative thymocytes. A subset of TCR $\gamma \delta-C D 3+$ cells co-expresses CD1 in the thymus but not in the periphery. Others have previously shown expression of CD1 on TCR $\alpha \beta$-CD3tow or - double-positive cortical thymocytes but not on peripheral T cells $(4,5,9,13)$. CD1 expression is therefore restricted in $\alpha \beta$ and $\gamma \delta$ linkages to an intrathymıc phase of development.

The in vitro assays for function show that the CD1+ doublenegative subsets behave as inert cells whereas some cells among elther CD1-3- precursors or their progeny (CD1-3+ doublenegative thymocytes) are functionally competent. A striking aspect of this finding is that cell responsiveness does not appear to be associated with cell-surface TCR-CD3 expression. Previous studies have shown that CD1 occurs on most double- postive thymocytes which are functionally incompetent cells despite the cell-surface expression of TCR $\alpha \beta-\mathrm{CD} 3$ on half of them $(4,5,9,13,28)$ The functional competence of some CD1-, TCR - CD3-4-8- thymocytes has been definitively established with the development of several clones with such phenotype that use the IL2 pathway of proliferation in vitro (P.Aparıcio et al, unpublished observations) Our results also suggest that not all $\gamma \delta$ T cells are born immunocompetent.

It could be argued that the binding of anti-CD1 antibody to the cells might itself cause $\mathrm{CD} 1+$ thymocyte unresponsiveness prior to assays of function However, this is ruled out by the following (i) separation of CD1+ thymocytes by negative selection of CD3bright or CD44(Pgp-1) + thymocytes yields also functionally inert CD1 + cells $(28,29)$; and (II) the addition of saturating amounts of anti-CD1 antibodies does not inhibit cell proliferatıon, IL2 secretion, or IL2-R acquisition in the Jurkat thymoma, cells which co-expresses TCR $\alpha \beta$ and CD1 (A. de la Hera, unpublished observations). We conclude that there is a tight Inkage between CD1 expression and incompetence in assays of function in vitro among human thymocytes. Indeed, the precursor frequencies for CD1+ cells responding to PHA plus IL2 are always very low ( $<1 / 100$ cells), and all growing $T$ cells thus far studied are CD1- (28). Also, mature $\alpha \beta$ and $\gamma \delta T$ cells, of double-negative, double-positive, or single-positive phenotypes, can be cloned from CD1- thymocytes after stımulation with PHA plus IL2, with high plating efficiencies in vitro ( $\sim 1 / 2$ cells; 28 and our unpublished results).

We have studied the differentiation potential of the $\mathrm{CD} 1+3-$ double-negatives. We show that they pass through a CD3-4-8+ intermediate en route to the major $\left(C D 1^{+}\right)$doublepositive thymocyte population. The precursors are IL2-R- and do not require the addition of exogenous IL2 for their differentiation. In our previous studies we removed the CD1+ population from isolated CD4-8- thymocytes prior to culture and hence did not find CD1+4+8+ thymocytes (3). Simılarly, in the mouse it was shown that only the IL2-R- Thy-1'm subset of CD4 - 8- thymocytes generates immature CD4+8+ cells in vitro $(30,31)$. Most CD1 + double-positive thymocytes generated in vitro bear cytoplasmic TCR $\beta$ chain, indicating that they are $\alpha \beta$ pre-T cells, and some may express low levels of TCR - CD3 on the cell membrane. CD1 + TCR - CD3 + thymocytes cannot be expanded in vitro, nor can normal peripheral mature CD1+ $\mathrm{T}$ cells be detected ex vivo (Table 1; unpublished observations).

Interestingly enough, a minor subset $(<5 \%)$ of $\mathrm{CD} 1-3+$ double-positives occurs in vivo We have previously shown that polyclonal activators such as PHA and IL2 stimulate the generation of such $\mathrm{CD} 1-3+$ double-positives from CD1double-negatives in vitro (32). CD1-3+4+8+ thymocytes are functionally competent and can proliferate in the presence of IL2 $(32,33)$. We therefore conclude that $\mathrm{CD} 1+$ and $\mathrm{CD} 1-, \mathrm{CD} 4-8-$ cells can act as precursors for two distinct subsets of doublepositive thymocytes in vitro. Experiments are underway to define at the molecular genetic level whether the mature CD1- doublepositives are the intermediate stage in the generation of $\mathrm{CD} 4+8-$ and $\mathrm{CD} 4-8+\alpha \beta$ T cells (33).

In summary, CD1 antigen is expressed early in ontogeny by double-negative thymocytes including TCR-CD3+ T cells. $\mathrm{CD} 1$ + double-negative thymocytes are precursors of doublepositive thymocytes which show no functional competence in vitro. Inducibility of IL2 pathway responsiveness in vitro occurs 
in some $T$ cell precursors before CD1, TCR-CD3, CD4, and CD8 expression. At later stages of development, there is a good correlation between cell unresponsiveness in vitro and CD1 expression, both on cell-surface positive and negative $\alpha \beta$ and $\gamma \delta$ TCR - CD3 cells

Such studies have been pertormed in vitro. What can be the putative implications of these findings to the situation in vivo? It has been estumated that $-95 \%$ of thymocytes die intrathymically, most likely at the inert double-positive thymocyte stage $(7,8)$ it is generally thought that the cells that are elımınated have been tolerized or would never terminally differentiate $(7,8)$. The reason that receptor occupancy leads to clonal deletion in the immature thymocytes, instead of the clonal expansion observed in mature $T$ cells, is unknown, but the occupancy of CD4/CD8 has been implicated in this process $(30,34,35)$ We and others have previously shown that CD1 is covalently associated with CD8 on the surface of double-positive but not mature thymocytes, that functionally competent CD1 + thymomas exist but do not assemble CD1 multimolecular complexes, and that functional CD1 - double-positive thymocytes do exist $(13,32,33,36,37)$. In light of these findıngs, we shall test the possibility that such CD1 multımolecular complex expression Is, perhaps, related to the mechanisms that lead to a selective elimination of immunologrcally unresponsive cells in the thymus.

\section{Acknowledgements}

We thank Jose-Carlos Gutierrez-Ramos, Klaus Kanalainen, Polly Matzinger, and Ron Palacios for the discussion and suggestions, the Thoracic Surgery Unit, Kantonsspital, Basel and the Paediatric Cardiosurgery Unit, CERyC, Madnd for the thymus samples, Drs A. Bernard, M Brenner, T Hercend, M. Lopez-Botet, C. Mawas, M. O. de Landazur, F. Sanchez-Madnd, and J. de Vries for the antibodies, Drs R. Peck and F Sinigaglia for the rIL $1 \beta$ and rIL2, Mr H. P. Stalhberger for the artwork, and D Thorpe for technical assistance. The Basel Institute was founded and is supported by Hoffmann-La Roche Ltd, Basel, Switzerland. This work was partially supported by CICyT, W.W Foundation and FISS A H. is on leave of absence from the Centro de Investıgaciones Bıologicas, CSIC, Madrid

\section{Abbreviations}

CD

FC

FITC

mAb

$\mathrm{MHC}$

PE

PHA

$\mathrm{rlL}$

TCR cluster of antibodies directed to differentiation antigens

flow fluorocytometry

fluorescein isothiocyanate

monoclonal antıbody

major histocompatıbility complex

phycoerythrin

phytohemagglutının

recombinant interleukin

$\mathrm{T}$ cell receptor

\section{References}

1 Moller, G. ed. 1984 T-cell receptors and genes. Immunot. Rev. 81

2 Palacios, R. and Pelkonen, J. 1988. Prethymic and intrathymıc T-cell progenitors Immunol Rev 104:5.

3 Toribło, M. L , Alonso, J. M., Barcena, A, Gutierrez, J C., de la Hera, A. Marcos, M. A. A, Marquez, C, and Martunez-A., C. 1988. Human $T$-cell precursors. Involvement of the interleukın 2 pathway in the generation of mature $T$ cells Immunol Rov. 10455.

4 Reinherz, E. L and Schlossman, S. F. 1980. Discrete stages of human intrathymic differentiation. anabysts of normal thymocytes and leukermia lymphoblasts of T cell lineage. Cell 19:821
5 Allison, J. P. and Lanier, L. L. 1987. Structure, function and serology of the T-cell antıgen receptor complex. Annu Rev. Immunot. 5.503

6 Fowikes, B J, Edison, L., Mathieson, B. J., and Chused, T. 1985. Early thymocytes. Differentiation in vivo of adult intrathymıc precursor cells. J. Exp Med 162:802.

7 Scollay, R., Bartlett, P., and Shortmann, K 1984. T cell development In the adult munne thymus Immunol Rev. 82:79.

8 von Boehmer, H , Teh, H S., and Kisielow, P. 1988. Thymus selects the useful, neglects the useless and destroys the harmful. Immunol. Today 10.57

9 Tsoukas, C. D., Landgraf, B , Bentun, J , Lambert, J. F., Carson, D A., and Vaughan, J. H. 1987. Structural and functional characteristics of the CD3(T3) molecular complex on human thymocytes $\mathrm{J}$. Immund. 138.3885

10 Havran, W. L, Poenie, M, Kimura, J , Tsien, R, Weiss, A, and Alison, $J$ P. 1987 Expression and function of the CD3-antigen receptor on murine CD4+8+ thymocytes. Nature 300:170.

11 Finked, T. H., McDutfie, M., Kappler, J. W., Marrack, P, and Cambier, JC 1987. Both immature and mature T cells mobilize $\mathrm{Ca}^{++}$in response to antigen receptor crosslinkıng. Nature 300.179.

12 McMichael, A J., Pilch, J. R., Galfre, G , Masson, D Y., Fabre, J. W , and Milstein, C 1979. A human thymocyte antugen defined by a hybnd myeloma monoctonal antibody. Eur J Immunot. 9205.

13 Sanchez-Madnd, F., Tonbio, M L , Gambon, F., and O. de Landazuri, M 1985 Cell surface molecular changes on the activation of human thymocytes J. Immunol. 135:3938.

14 Blue M.-L., Daley, J F., Levine, H, and Schlossman, S F. 1985. Coexpression of $\mathrm{T} 4$ and $\mathrm{T} 8$ on peripheral blood $\mathrm{T}$ cells demonstrated by two-colour fluorescence flow cytometry. J. Immunol. 134:2281.

15 de la Hera, A., Toribio, M. L., Marcos, M. A R., Marquez, C., and Martinez-A., C. 1987 . Interleukin 2 pathway is autonomously activated in human $\mathrm{T} 11+3-4-6-8-$ thymocytes Eur. J Immunol 17:683.

16 Carrera, A.C , Sanchez-Madrid, F , Lopez-Botet, M., Bernabeu, C., and $O$ de Landazuri, M. 1987. Involvement of the CD4 molecule in a postactuvation event in T-cell proliferation. Eur. J. Immund 17.179.

17 Spits, H., Yssel, H , Leewenberg, J., and de Vnes, J. E. 1985. Antigenspecific cytotoxic $T$ cells and antigen specific prolferating $T$ cell clones can be induced to cytotoxic activity by monoclonal antibody agannst T3. Eur J. Immunot. 15.88

18 Malissen, B, Rebai, N, Liabeut, A, and Mawas, C. 1982. Human cytotoxic $T$ cell structures associated with the expression of cytotysis. Eur J Immunol. 1588

19 Spits, H , Borst, J., Tax, J., Caped, J. P A., Terhorst, C., and de Vnes, $J E 1985$ Characterization of a monoclonal antibody (WT31) that recognizes a common epitope on the human $T$ cell receptor for antıgen. J. Immunot 135.1922.

20 Band, H., Hoshtenbach, F., McLean, J , Hata, S., Kranged, M S., and Brenner, M. B 1987. Immunochemical proof that a novel rearranging gene encodes the $T$ cell receptor $\delta$ subunit. Science 238.682

21 Trebet, F, Faure, F., Graziani, M, Jitsukawa, S., Lefranc, M.P , and Hercend, T. 1988. A unique V-J-C-rearranged gene encodes a $\gamma$ protein expressed on the majority of $\mathrm{CD}^{+}{ }^{+} \mathrm{T}$ cell receptor $\alpha \beta$ circulating lymphocytes J Exp. Med. 167:694.

22 Toribıo, M L., de la Hera, A , Borst, J., Marcos, M A. R., Marquez, C. Alonso, J. M., Barcena, A, and Martinez-A., C 1988. Involve ment of the interleukin 2 pathway in the rearrangement and expression of both $\alpha \beta$ and $\gamma \delta$ T cell receptor genes in human T cell precursors J. Exp. Med. 168:2231.

23 Toribio, M. L., de la Hera, A., Regueiro, J. R., Marquez, C., Marcos, M. A. R., Bragado, A., Arnaiz-Villena, A., and Martunez-A., C. 1988 $\alpha / \beta$ heterodimeric $T$-cell receptor expression in earty thymocyte differentiation. J. Mol. Cell Immunol. 3.347

24 Bank, I., DePinho, R. A., Brenner, M. B., Cassmeris, J, Att, F. W., and Chess, L. 1986. A functional T3 molecule associated with a nove heterodimer on the surface of immature human thymocytes Nature 322179

25 de la Hera, A, Tonbto, M. L, Marquez, C., and Martnez-A., C. 1985 Interleukın 2 promotes growth and cytolytic activity in $\mathrm{T} 3+4-8-$ thymocytes. Proc. Nat. Acad. Sci. USA 82:6268.

26 Fowkes, B J., Kruisbeek, A M., Ton-That, H., Weston, M. A., Coligan, J. E., Schwartz, R. H, and Pardoll, D. M. 1987. A noved population of T-cell receptor $\alpha / \beta$-bearing thymocytes which predominanthy expresses a single $V_{\beta}$ gene family Nature 329.251 . 
27 Lanier, L L., Rultenberg, J, Bolhuis, R. L H , Borst, J., Philips, J. H. and Testı, R. 1988. Structural and serological heterogenerty of $\gamma / \delta$ $T$ cell antigen receptor expression in thymus and peripheral blood. Eur. J. Immunol 18.1985.

28 Lopez-Botet, $M$ and Moretta, A. 1985. Functional analysis of human thymocytes $J$ Immunol 134:2299

29 Haynes, B. F., Harden, E .A., Teten, M. J., Hemler, M E , Strominger, J E, Palker, T. J, Scearce, R M., and Elsenbarth, G S 1983. Differentiation of human thymocytes. I. Acquisition of a novel human cell surface protein $(p 80)$ during normal Intrathymic T cell maturation $J$ Immunot. 131.1195.

30 MacDonald, H. R., Howe, R C , Pedrazını, T., Lees, R. K., Budd, R. C, Schneider, R, Lao, N. S., Zinkernaget, R M L Louls, J A, Raulet, D H. Hengartner, H., and Miescher, G. $1988 \mathrm{~T}$ cell ineages, repertoire selection and tolerance induction Immunol. Rev. 104157

31 Nakano, N., Hardy, R. R., and Kishimoto, T. 1987 Identufication of intrathymic T progenitor cells by expression of Thy-1, IL2 receptor and CD3. Eur. J Immunol. 17.1567

32 de la Hera, A., Tonbio, M L, Marquez, C., Marcos, M. A R, Cabrero, E., and Martınez-A., C 1986. Differentiation of human mature thymocytes. existence of a T3+4-8- intermediate stage Eur. $J$ Immunot. 16653.
33 Blue, $M$ L, Daley, J F., Levine, H , Craig, $K A$, and Schlossman, S. F 1987 Identification and isolation of a T4 +8+ cell with high T3 expression in human thymus a possible late intermediate in thymocyte differentiation. J. Immunol 139.1065

34 Kappler, J W, Roehm, N., and Marrack, P 1987. T cell tolerance by clonal elimination in the thymus Cell 49.273

35 Fowkes, B. J., Schwartz, R. H., and Pardofl, D M 1988 Delection of self-reactive thymocytes occurs at a $\mathrm{CD} 4+8+$ precursor stage Nature 334620

36 Snow, P. M, Van De Rijn, M, and Terhorst, C 1985 Association between the human differentiation antigens $T 6$ and T8 Eur. $J$ Immunol. 15:529

37 Amıot, M., Dastot, H. Schmid, M., Bernard, A., and Boumsell, L. 1987 Analysis of CD1 molecules on thymus cells and leukemic T lymphoblasts identifies discrete phenotypes and reveals that CD1 intermolecular complexes are observed onty on normal cells Blood 70.676

38 Brottier, P. Boumsell, L, Gelın, C., and Bernard, A 1988. T cell actrvation via CD2 [T,gp50] molecules J Immunol. 135.1624

39 Carrera, A. C., Rincon, M., Sanchez-Madrid, F., Lopez-Botet, M., and $O$. de Landazurı, M. 1988 Triggerıng of co-mitogenic signals in T cell prolferation by antr-LFA-1 (CD18, CD11a), LFA-3, and CD7 monoclonal antibodies $J$ Immunof 1411919. 